\title{
Sustainable Maintenance of Navigation Channel: The Case of Port Tanjung Pelepas (PTP) Port
}

\author{
O. O. Sulaiman \\ Faculty of Maritime Studies and Marine Science, Universiti Malaysia Terengganu \\ 21030 UMT, Kuala Terengganu, Terengganu, Malaysia \\ E-mail: o.sulaiman@umt.edu.my,sdin@umt.edu.my \\ A.H. Saharuddin \\ Faculty of Maritime Studies and Marine Science, Universiti Malaysia Terengganu \\ 21030 UMT, Kuala Terengganu, Terengganu, Malaysia \\ E-mail:sdin@umt.edu.my
}

A.S.A. Kader

Faculty of Mechanical Engineering, Department of Marine Technology, Universiti Technologi Malaysia 81300 Skudai, Johor, Malaysia

Tel: 60-19-717-5860Ｅ-mail: abdsaman@fkm.utm.my

\author{
Received: February 28, $2011 \quad$ Accepted: July 5, $2011 \quad$ Published: December 1, 2011 \\ doi: $10.5539 /$ ass.v7n12p175 \\ URL: http://dx.doi.org/10.5539/ass.v7n12p175
}

\begin{abstract}
Maritime industry is the cradle of all modes of transportation where port is and ship is necessary to facilitate trading through marine transportation. Human development and demand for international trade has resulted to need for economic of large scale for ships. Recently, there is continuous growth or need for larger and sophisticated ship through increasing shipping activities and this has lead to design and production of sophisticated state of art safety oriented marine vehicle in term of size, speed and structure- albeit, this safety based designed development is out of phase with conditions of navigation channels. To create a balance for safe navigation in inland port which are considered to be restricted water, this big ships will ply, it is necessary to maintain the channel to keep accepting the target largest vessel, and the channel should be maintain at frequency the ship building are growing. This paper presents the result of application of best practice simplified method for channel maintenance against vessel design and reception requirement. The model is used to calculate channel dept requirement to be maintain for Port Tajun Palapes (PTP) in Johor, Malaysia which arrived at 15.2. The paper also discusses reservation regarding sustainability reservation requirement for channel maintenance
\end{abstract}

Keywords: China insurance industry, Foreign fund, Challenge

\section{Introduction}

Recent time has proved continuous growth or need for larger and sophisticated ship through increasing shipping activities and demands, this has lead to design and building of sophisticated, state of the art, safety oriented marine vehicles in term of size, speed and structure, albeit, the design and production of vessels take little consideration in phasing them with navigation channel requirement of waterways. To create a balance for safe navigation in restricted water these big ships will ply, we must maintain the channel at a frequency the ships building are growing. Maintenance dredging is the activity that involve periodic removal of material which has been deposited in an area where capital dredging has been undertaken, The frequency of maintenance dredging varies from port to port, however, the objective remain to allow ships to enter and leave port at stated draft without delay and ensure efficiency of maintenance dredging, thus step must be taken during the process to minimize siltation and shoaling in channel. 


\subsection{Shipping trend}

Ships and shipping remains a very important instrument for mobility, if ships could no longer transit the waterways, the people will experience shortages of power, heat and food in days or weeks at the outside. Recent years have seen economic of scale due to improved trade, the significance of these trends is that larger ships will continue to use our waterways for the foreseeable future. But there are limits on size of ship that a channel can accommodate, and means of determining when special measures must be imposed on handling ships in order to ensure the continued safe, efficient, and environmentally friendly use of our channel.

To create a balance for safe navigation in restricted water this big ship will ply, and the channel at a frequency the ship production are growing must be maintained. Recent study provided data on the explosion in the size of container ship that has occurred since the first "post Panama " vessel analysis shows that ships exceeding the panama canal limit (ship length, breath draught of $256 \mathrm{mx} 32.2 \times 11 \mathrm{~m}$ ) started to appear a few years ago. Other study mad by transmarine also demonstrated that recent time is seeing vessel of size up to $18,000 \mathrm{TEU}$ Mongelluzo (2005. See figure 1 for growing size of ships as presented by Transmarine.

$<$ Insert Figure 1 Here $>$

RINA periodic recently report that Maesrk line has built 14, TEU ship that is ready for operations, however, safe operation of those big will be operated remain is under deliberation. This show the rapid the growing trends of container vessels and need of channel to match this growth. Recent projection is looking at 18,000 TEU Which I believe the technological capability is there for such target. As the ship sizes are increasing it is imperative to do periodic examinations of the requirement of the channel in regards to depth, width, squat, and alignment. Figure 2 shows the needs of the channel.

Channel design and maintenance work fall among the works that require multivariable exercise that need model studies for good outcome. Shoaling remaining unavoidable part of most harbor and navigation channels and one method to preventing shoaling and associated siltation hurdles is using of maintenance dredging at economical frequency and sustainable manner .other study on ship size in respect to channel stressed on the fact that the design of controllability of the ship is equally out of match with the size of the ship, all what has been the main focus on design spiral is best design of basic requirement of speed, payload and endurance - focus is not placed neither on channel design nor its maintenance Talley (2000)..

\subsection{Present threat}

Growing size of fleets and lack maintenance of channel has been going in human society for a long time, (INTERTANKO report in 1996 on the same issue regarding US water). Analysis drawn from marine departments revealed that disasters records of the Strait of Malacca collision where grounding takes the highest share of the risk, Risk in the Strait of Malacca. Norske Veritas study on various navigation water ways put present the Strait of Malacca as one of the high risk areas of the world. This issue is considered very necessary and required diligent attention, especially in protected water and restricted water like the needy patronized Strait of Malacca and its riparian which PTP is part of - where more than 800 ships pass through there a day, accident and causality figure by Malaysian marine department.

Analysis made by the UNEP regarding region under coastal threat concluded that Asia coast is far more affected, because Asia have the largest river runs off to the sea than any other continent. According to UNEP report maintenance of navigation channel remains one sensitive area of environmental degradation concern for environmental thematic problem especially dredging, its disposal disturbance to marine life Burt, et. al. (1997).

$<$ Insert Figure 2 Here $>$

\subsection{Pollution source and impacts to port}

The pollution found in the sediments that accumulate in harbors is one of the main causes of environmental impact of dredging operations. This is important feature since harbor waters and sediments are heavily polluted worldwide- containing high levels of a range of chemicals. The sources of pollution are multiple; in many cases they are linked to the harbor activity. TBT (tributyltin), is a compound used as antifouling that has been recognized as a harmful pollutant and whose use has been restricted at the international level. However, the problems caused by TBT will continue for many years, because TBT is kept stored in the harbor sediments. The main source of TBT to marine waters is the direct release from surfaces treated with antifouling paints containing TBT and other organotin compounds Csiti, et al (1999).

They have been used in order to prevent the attachment of aquatic organisms on the hull of ships or other devices that are immersed in the sea, such as the cages used for fish-farms (Evans, 2000). Paints incorporating TBT are 
regarded as the most effective antifoulants ever devised giving rise to important economic benefits. Their use reduces the fuel consumption of the vessels (and thus reduces $\mathrm{CO} 2$ emissions), ships can go faster, and repainting costs are lower. Little is still known of the effects on marine organisms of dredging operations contaminated sediments, and the need of research on this issue is often claimed Evan (2000).

To assess the potential impacts of a certain project is a difficult task. First, although the (a priori) main possible impacts of dredging can be identified, clearly it is not possible to review all the potential effects; once the impacts of concern are selected, it might be costly, complex or impossible to assess the extent and the consequences of each of the effects caused by the activity assessed.. Consequently, the dredging operation causes the resuspension of sediments, solids in water to some extent produces an effect called turbidity, which is defined as an optical property of water related to attenuation of light (Peddicord and Dillon, 1997). Other factors influence the level of turbidity (such as size distribution and shape of particles). Although, they are regarded as "short-term" impacts, the presence of large quantities of particles in the water can cause serious effects in areas where the system is not used to it, and particularly to sensitive species or areas (for example, coral reefs or aquaculture ponds), as well as reduction of oxygen in water, release of toxic components from suspended solid, covering of organisms, reducing food supply, etc (Bray, 2001). Moreover, lack of light may reduce photosynthesis, which might be relevant for sensitive species.

This make it incumbent for authorities concerned regarding waterways to evaluate and address the risks associated with ships that are plying them and find way and information sharing avenue systems for channel designers, naval architects, ship masters and pilots, and waterway managers that will help develop policy recommendations that will address the way channels are laid out, enlarged and how ships of various types using them should be designed and handled Funtowicz (2004).. And of course, ways to monitor existing and new ships operating at channel approach in order to guide ship designers to understand and review ships, pilotage, channel, current design and operational practices on how to incorporate needed improvements Bridges (2001).

\section{The Case of Port Tanjung Pelepas}

The Port Tanjung Pelepas of the Sungai (river) Pulai located in Malay Peninsula's most southern tip in the State of Johor, close to the new Malaysia-Singapore Second Crossing, a new 1800-metre bridge linking Singapore with Malaysia's. The port development at Tanjung Pelepas is one unique state of art capital project design work done on sensitivity and helps transform the river and mangrove area in 1998 into one of the world's most equipped container port. it remain one the significant implementation of Malaysian VISION 2020 plan, a 60 years concession 60-year concession for 800 ha port with Free Zone Status was made to Seaport Terminal (Johor), under operation of her subsidiary company, Pelabuhan Tanjung Pelepas Sdn. Bhd of by Malaysian Government and syndicate of banks agreement of RM 2 billion loan. The port has stimulated rapid development in the region stretching from state capital Johor towards the west along the Johor Straits; it has changed the region to developed area with excellent infrastructure, housing facilities and new areas for industrial development.

\section{$<$ Insert Figure 3 Here $>$}

What necessitated the port development initiative is again the demand and growth since the seventies, with forecast for potential critical capacity problem by the year 2000. The Johor Port Authority reached maximum expansion of the Port area with the completion of Phase 4 of Pasir Gudang studies in 1990 end up with selecting Tanjung Pelepas as the most suitable location for Johor's.

\subsection{Previous dredging work}

The initial main dredging work done on Phase 1 of PTP development towards complementing a fully operational Container Terminal by end of 1999For the Dredging and Reclamation scoped for the removal by dredging of existing soft material to provide an approach channel, turning basin and bund foundation area and construction of the Wharf Bund and filling of the terminal and infrastructure areas to provide a stable platform for the Container Area. Summary of work done is as follows:

i. Year 1997; Contact cost - US\$ 158 million

ii. 200 hectares of Site Clearance, mangrove and bush clearing; Additional Site Investigation;

iii. Dredging of the 9-km long approach channel and turning basin, approx. volume 16,000,000 m3;

iv. Dredging to foundation level below Wharf Bund, approximate volume 5,500,000 m3;

v. Constructions of the Wharf Bund, approx. volume of sand 4,000,000 m3;

vi. Installation of $20,000,000$ meters of wick drains as ground treatment; 
Reclamation and surcharge of Phase 1 Area, Terra et Aqua - Number 80 - September 2000foundation area and construction of the Wharf Bund and filling of the terminal and infrastructure areas to provide a stable platform for the Container Area. Summary of work done is as follows :

vii. Year 1997; Contact cost - US\$ 158 million

viii. 200 hectares of Site Clearance, mangrove and bush clearing; Additional Site Investigation;

ix. Dredging of the 9-km long approach channel and turning basin, approx. volume 16,000,000 m3;

x. Dredging to foundation level below Wharf Bund, approximate volume 5,500,000 m3;

xi. Constructions of the Wharf Bund, approx. volume of sand 4,000,000 m3;

xii. Installation of 20,000,000 meters of wick drains as ground treatment;

xiii. Reclamation and surcharge of Phase 1 Area, Terra et Aqua - Number 80 - September 2000

The construction, completion, maintenance of the Dredging and Reclamation Works involved the dredging of $16,000,000 \mathrm{~m} 3$ of soft and stiff material to form a $12 \mathrm{~km}$ Access Channel and Turning Basin, together with the dredging of 5,500,000 $\mathrm{m} 3$ of soft to medium material from a trench to form the base for the new Wharf Structure. The initial activity concentrated on dredging an access of 12 metres deep, 100 metres wide and approx. 5000 meters long (pre-dredging depth only approximately 4 metres by low tide) to allow the jumbo hopper dredgers to reach the Site. Dumping ground -in the Malacca Straits northwest of Karimun and along the coast of Pontian up to $120 \mathrm{~km}$ from The Sand was won from Karimun southeast. The most economical filling method for the bund would have been:

i. Filling up to -6 to $-7 \mathrm{CD}$ direct dumping from a hopper dredger;

ii. From -6 to -7 to $+4 \mathrm{CD}$ rainbowing;

\section{Channel Maintenance Process}

Within the scope of this project the main elements that method will be faced are analysis of:

i. Channel dimension establishment through navigation requirements and Side slope tolerant

ii. Hydrographic and dredge volume concept, Calculation of yearly dredge quantity output

iii. Dredge capacity and selection of dredge equipment

iv. Disposal of dredge material, issue of transport distance and sustainability concept

v. Concept of uncertainty, risk cost and benefit assessment

$<$ Insert Figure 4 and Figure 5 Here $>$

\subsection{Navigation requirement}

Having got various vessels to channel equipment ratio, what the size of the channel should be and how much to dredge down can actually be determined.

\subsection{Maintenance dredging requirement}

Analysis will go through iterative round of all the thematic part of the project:

i. Need for channel maintenance

ii. Old, Current and new practice

iii. Technological change and opportunity

$<$ Insert Figure 6 Here $>$

Recommendation for channel deepening work requires the following:

i. Loaded vessel draft / Squat, this involve the hydrodynamic sinking effect of lowering vessel keel relative to channel bottom with speed.

ii. Wave induced motions, Safety clearance, Dredging tolerance

iii. Advance maintenance dredging

To determine this iterative process with regulatory requirement, necessary projection base on the following data parameter as shown in the framework for depth calculation will be performed.

$<$ Insert Table 1 Here $>$ 


\section{$<$ Insert Figure 7 and Figure 8 Here $>$}

This three studies have been done prior to establishment of PTP prior to the initial capital, however to maintain and capital dredging techniques for channel use similar process. Thus, methodology varies, and simplicity itself remains the beauty of design.

\subsection{Baseline Data Analysis}

The input parameters are used to develop the requirements and design considerations for channel width and depth, as demonstrated in the flow chart shown above which proves detail on the width and depth parameters. Input data is captured from baseline studies that are undertaken involving an analysis and evaluation of the following data supplied by PTP:

\section{Pressure Need for Navigation Optimizing Navigation Channel, Economic and Fairway Analysis}

The optimum channel depth requires studies of estimated costs, benefits and risk of various plans and alternative designs considering safety, efficiency, and environmental impacts in order to determine the most economical, functional channel alignment and design depth. Channel deepening design is often one of the major cost-determining parameters for navigation project and design of such depth is of various types that require adaptability of each design to future improvements for increased navigational capability.

$<$ Insert Figure 9 and Figure 10 Here $>$

The optimum economic channel is selected from a comparison of annual benefits and annual costs for each channel maintenance plans. Deeper channels will permit the use of larger ships, which are more economical to operate.

\subsection{Cost, benefit and depth increase}

In respect to PTP and channel maintenance work the following economic analysis based on need and projection datas analysis represent the demands stage of this work for the fairway.

$<$ Insert Figure 11 Here $>$

Studies made by W. Winkelman estimated time saving in hour as a consequence of deepening of river Scheldt by 4 feet is as follows:

$<$ Insert Figure 12 Here>

\subsection{Channel dimensioning: navigation vessel and channel requirement}

This involves the input variables required, to determine the minimum waterway dimensions required for safe navigation.

\subsubsection{Vessel requirement}

The critical component in the design of the waterway is the selection of the "target" vessel. In evaluating the waterway manoeuvring parameters, the target vessel is normally the largest vessel that the waterway is expected to accommodate safely and efficiently. The largest vessel that has plied PTP is $340 \mathrm{~m}$, and the channel is expecting to receive $420 \mathrm{~m}$ vessel.

$<$ Insert Figure 13 Here>

\subsubsection{Water level and depth of the waterway}

\section{$<$ Insert Figure 14 Here $>$}

For channel to accept ships there must be corresponding depth required to maintain vessel manoeuvrability. Therefore, minimum value for water depth/draught ratio is necessary to for assurance and reliability.

$<$ Insert Table 2 and Table 3 Here $>$

\section{Results}

Total Depth calculation: The design (authorized) depth will include the various allowances as shown in Figures. Advance maintenance and dredging tolerance are provided in addition to the design depth.

Minimum Waterway Depth for safe navigation is calculated from the sum of the draught of the design vessel as well as a number of allowances and requirements. The Canadian model the following recommended Canadian model formula is used.

Actual Waterway Depth $=$ Target Vessel Static Draught + Trim + Squat + Exposure Allowance + Fresh Water Adjustment + Bottom Material Allowance + Over depth Allowance + Depth Transition - Tidal Allowance, (see 
Figure 5: Components of Waterway Depth).

Channel (Advertised) Waterway Depth = Waterway Depth - Over depth Allowance

$<$ Insert Table 4 Here $>$

\subsection{Channel depth calculation for PTP}

$<$ Insert Table 5 Here>

Alternative equation for validation by UNDP

$\mathrm{H}=\mathrm{D}+\mathrm{Z}+\mathrm{I}+\mathrm{R}+\mathrm{C}+\#$

\subsection{Squat calculation}

$<$ Insert Figure 15 Here $>$

\subsection{Maintenance dredging capacity - sediments output and estimates}

Maintenance dredging with objective to reduce channel delay, accept big ship to be done in environmental sustainable manner and optimal efficiency -in maintenance dredging quantifying the loss of depth pave wave for dredging requirement to be determined and this lead to optimal choice of dredger. Thus PTP is a new port with very big clearance to accept third generation ships, personal communication with the health, safety and environmental department there also confirmed regular survey for siltation towards planning to maintain balance which is put at 2- 3 year for now( personal communication. Issue relating to investigation or communication about what size vessel will ply the channel in the 10 years is rarely discussed by channel workers, and this is a big issue and what to in such case should be a big issue.

Generic calculation on data results from analysis of:
i. Vessel and channel requirement
ii. Channel dimension
iii. Hydrographic data
iv. Basic rate output of the dredger
v. Computation of volume
vi. Cycle time and Number of work day per year
vii. Working condition and Environmental discounting

Where:

Output $=$ number of cycle per day X load factor $\mathrm{x}$ hopper capacity $\mathrm{x}$ number of working day

Load factor $=$ volume/ hopper volume

Number of working day per year $=365$ days

For PTP:

$<$ Insert Table 6 Here $>$

Alternative equation for validation (USACE) -> V=0.5x (A1+A2) x (S2-S1)

\subsection{Dredger selection}

Hydraulic dredgers, for example, are based in the use of pumps for raising the materials (suction dredgers). The dimension of dredging as an economic activity itself at the global level is considerable. The other main group is that of mechanical dredgers. Such as the backhoe Previous PTP dredging work was made using state of art combo slip hopper barge dredger, uniqueness in this dredger stand on capacity to contain dredge material while in operation, transit until disposal location, (personal communication).

Split hopper dredger is a modern hydraulic excavator, mounted on a platform fixed to the seabed. The material is excavated by the bucket of the excavator, kept and contained. Then is raised above water and transported directly to the disposal site. The soil at PTP is basically silt and mud, and the dredgers well sweated for this. Accuracy is only achieved if monitoring and control equipment are used. Thus, the containment has guarantee of no leakage during transportation.

The volume of soil is very important in dredger selection, a smaller and more economic and environmental sustainable dredger is preferred. 
$<$ Insert Table 7 Here $>$

Considering PTP specification grab hopper is a good choice of dredger, for maintenance dredging. Traditionally, dredging quantities for purposes of design estimates and construction payment have been obtained from cross-sectional surveys of the project area. These surveys are normally run perpendicular to the general project alignment at a predetermined constant spacing. The elevation data are plotted in section view along with the design/required depth and/or allowable over depth templates. One or more reference or payment templates may be involved on a dredging project (e.g., zero tolerance, null ranges, etc.). Given sectional plots of both preconstruction and post construction (as-built) grades (or, in some cases, intermediate partial construction grades), the amount of excavated (cut) or placed (fill) area can be determined at each cross section. Figure shows the typical templates used to compute relative cut/fill quantities.

\section{Conclusion}

Conclusively, in regards case studies and the discussion presented here, I would like to highlight some of the main lessons that I think might be extracted from them. They are reflections that hopefully could be helpful for understanding the meaning and relevance simplified monitoring procedure, understanding and the concept sustainability in practical cases of environmental management. The model tested in this work from the records will allow us a first look at the simple system for monitoring the channel and to draw the following conclusions, The depth of the channel is large; approximately $16 \mathrm{~m} \times 420$ and taking ships in the order of approximately $350-420 \mathrm{~m}$ LOA But there is tendency that the channel wil soon get close to its limit. The rate of design ship to the channel state still exhibits non-linear behavior; bigger ship is coming there and the channel remains the same. The best that could be done is removing the shoal. $20 \mathrm{~m}$ is projected against 2020 , to meet the demand, however but. Critical study and employing a sustainable risk based methodology with good record of environmental change rationalization will be necessary. The phenomena of squat its effect are of major importance to the system ,applying simplifies model tested in this work could help close monitoring towards reliability and confidence of the channel .

Approximately 600,000 million cubic yards of sediment will be dredged annually from the navigable water, and the condition environmental change of such sediment required. The contaminants of concern and their risk to the environment and to humans will vary widely depending upon site-specific factors ranging from ecological habitat to sediment particle size distribution. The soft alluvium in previous work allowed consolidate under high surface loads, resulting in settlement of finished ground surfaces, however continuous analysis on geo-technical engineering studies will always be required to complement sustainable planning work. Facing capacity difficulties are issue of concern everywhere today particularly the fate of the channels. Demand for ship has approached supply and the tradeoffs will be more and more carefully scrutinized by the resources available and environmental demands. The channel is very important for land and land use, and safety linked to environment required, as demands of the ship increase so does the need for system integration at local and international level.

\section{The Way forward}

Waterways development need to have a strategy for the future of its marine structures program by examining the removal of non-core operations, and negotiate responsibilities for water depth forecasting with the Hydrographic Department. The case tests how to develop plans for simple waterways performance measurement information system, it is recommended that such method could be incorporate could tap existing information and communication to link reporting system of data to National Channel Inventory system. Such system could be implemented in line with the accountability framework), in order to provide improved monitoring and performance reporting capability on measures and indicators such as: channel monitoring level of service compliance; subject matter expertise level of activities; timeliness of notification to mariners; and actual repairs to structures versus required. Under doctrine of sustainability, it has been widely accepted that new approach to design and maintaining system should focus on top down risk based, whose matrix will holistically cover all issues of concern including uncertainty. Uncertainty itself remains a big issue who's definitional and framing fall under complex circumstance. Future studies on this work then lies on issue of risk based assessment for channel design and decision support system, simple data inventory system, system integration, and extensive studies that cover type of uncertainty that exist.

\section{References}

Bray, Nick. (2001). IADC-CEDA Guide 7, Frameworks, Philosophies and the Future. The Hague, The Netherlands. pp. 35-38. EPA Guidance Manual, Turbidity Provisions, April 1999. [Online] Available: http://www.epa.gov/volunteer/stream/vms55.html 
Bridges, J. W. and Bridges, O. (2001). Hormones as growth promoters: the precautionary Principle or a political risk assessment? In: Late lessons from early warnings: the precautionary principle 1896-2000. European Environmental Agency (ed.) Environmental Issue report No 22.

Burt, N., C. Fletcher, and E. Paipai. (1997). Guide 2B. Conventions, Codes and Conditions: Land Disposal. Environmental Aspects of Dredging. IADC and CEDA (eds.) TheNetherlands.

Craye, M. (2004). Interactive uncertainty assessment through pedigree-based tools: what, why and how? European Commission-Joint Research Center. Ispra. Italy.

Csiti, A. and Burt, N. (1999). Guide 5. Reuse, recycle or relocate. In: Environmental Aspects of Dredging. IADC and CEDA (eds.). The Netherlands. Proceedings of the International Symposium on Uncertainty and Precaution in Environmental Management. Technical University of Denmark. Copenhagen, June 2004.102

Evans, S. M. (2000). Marine Antifoulants. In: Seas at the Millennium: An Environmental Evaluation. Sheppard, C. (ed.). Elsevier Science, pp. 247-256.

Funtowicz, S. O. (2004). Models of Science \& Policy: From Expert Demonstration to Post Normal Science. Proceedings of the International Symposium on Uncertainty and Precaution in Environmental Management. Technical University of Denmark. Copenhagen, June 2004.

Gibbs, P. E., Bryan, G. W., Pascoe, P. L. and Burt, G. R. (1987). The use of the dogwhelk (Nucella lapillus) as an indicator of TBT contamination. Journal of the Marine Biological Association of the United Kingdom, 67: 507-524, 103.

Mongelluzo, Bill. (2005). Landside Logjam: New generation of big ships will force ports, railroads to change operations. Journal of Commerce.

Peddicord, Richard and Dillon, Thomas M. (1997). IADC-CEDA Guide 3, Investigation, Interpretation and Impact. The Hague, The Netherlands. pp. 53-55.

Talley, Wayne K. (2000). Ocean Container Shipping: Impacts of a Technological Improvement. Journal of Economic Issues, Vol. 34, No. 4, December.

U.S. Port and Terminal Safety Study. (1996). INTERTANKO/

UNEP. (2008). [Online] Available: http://www.grid.unep.ch/activities/assessment/indianocean_crisis/index.php

Table 1. Navigation depth parameters requirement

\begin{tabular}{|c|c|}
\hline Depth parameters & Subparameters \\
\hline Draught & vessel static draugh \\
\hline Trim & Vessel depth \\
\hline Squat & Vessel speed, draught, channel depth, block coefficient \\
\hline $\begin{array}{l}\text { Exposure } \\
\text { allowance }\end{array}$ & Vessel size, traffic density, local wave climate \\
\hline \begin{tabular}{|r} 
Fresh \\
\\
allowance
\end{tabular} & Water salinity and vessel size \\
\hline $\begin{array}{r}\text { Maneuvering } \\
\text { allowance }\end{array}$ & Channel bottom, operational characteristics, vessel speed and controllability \\
\hline $\begin{array}{l}\text { Overdepth } \\
\text { allowance }\end{array}$ & Nature channel bottom, dredging tolerant and siltation \\
\hline $\begin{array}{r}\text { transition Depth } \\
\text { allowance }\end{array}$ & Sudden change in channel depth \\
\hline Tidal allowance & Reference datum, highest and lowest level tidal window \\
\hline
\end{tabular}


Table 2. PTP channel parameters

\begin{tabular}{|c|r|}
\hline Width & 250 \\
\hline Manoeuvring lane & 1.6 to 2.0 times vessel beam \\
\hline The ship clearance lanes & $80 \%$ of the vessel beam \\
\hline Bank clearance & $80 \%$ of vessel beam is added to both sides of the channel \\
\hline Depth & $12.5 \mathrm{~m}$ (Bellow MLLW) related to LAT \\
\hline Under keel clearance & $1 \mathrm{~m}$ \\
\hline Safety clearance & \\
\hline maintenance & 0.3 \\
\hline Advanced $\quad$ & $600 \mathrm{~m}$ \\
\hline Turning basin & \\
\hline TEU estimate & $18 \mathrm{~m}$ below LAT with containment dike for future dredging \\
\hline Berth & $350 \mathrm{~m}$ wide by 20m with turning basin of 750m diameter \\
\hline Projection & $1: 8$ to $1: 6$ vertical: horizontal) for silt and mud- assumption at \\
\hline
\end{tabular}

Table 3. Environmental criteria [PTP]

\begin{tabular}{|c|c|c|c|c|}
\hline POS & PARAMETER & DATA/SIZE/DIMENTION & SOURCE & \\
\hline 14.3 .1 & $\begin{array}{l}\text { MAX WIND SPEED DURING } \\
\text { VESSEL BERTHNG }\end{array}$ & $22 \mathrm{M} / \mathrm{S}$ & $\begin{array}{l}\text { MASTER } \\
\text { VOL. } 2\end{array}$ & PLAN \\
\hline 14.3 .2 & MAX WIND AT BERTH & $27.7 \mathrm{M} / \mathrm{S}$ & $\begin{array}{l}\text { MASTER } \\
\text { VOL. } 2\end{array}$ & PLAN \\
\hline 14.3 .3 & $\begin{array}{lll}\text { MAX } & \text { SIGNIFICANT WAVE } \\
\text { HIGHT } & \end{array}$ & $\operatorname{Hmax}=1.2 \mathrm{~m}$ & $\begin{array}{l}\text { MASTER } \\
\text { VOL. } 2\end{array}$ & PLAN \\
\hline & WAVE PERIOD & $\mathrm{Ts}=4-5 \mathrm{sec}$ & $\begin{array}{l}\text { SELLHORN } \\
\text { WAVE CAL. }\end{array}$ & WIND \\
\hline 14.3 .4 & MAX. RIVER CURRENT & $1.0 \mathrm{~m} / \mathrm{s}$ & $\begin{array}{l}\text { MASTER } \\
\text { VOL. } 2\end{array}$ & PLAN \\
\hline
\end{tabular}

Table 4. PTP Water depth

\begin{tabular}{l|l|} 
Weter way depth & 16.5 \\
Over depth allowance & 0.5 \\
Advertised depth & 16 \\
Wuter way depth & 16.5 \\
Oer depth allonemos & 05 \\
\hline & \\
Adveti sed depth & 16 \\
\end{tabular}


Table 5. Channel depth calculation

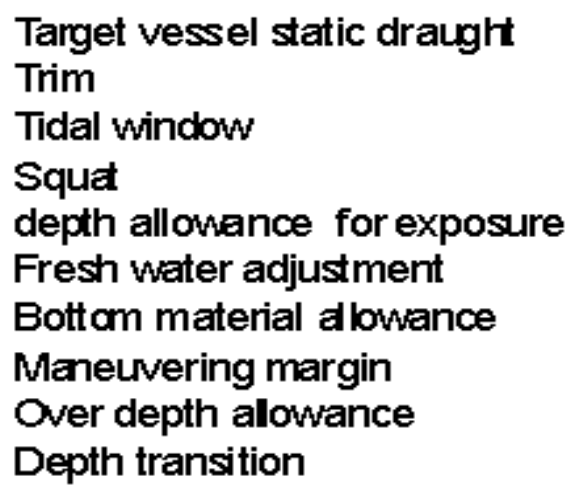

Depth

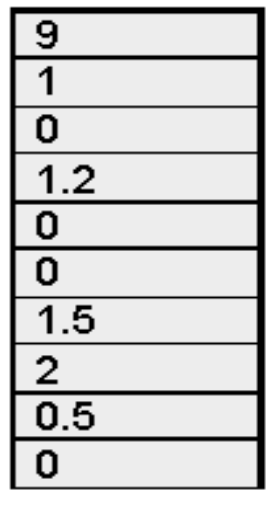

15.2

Table 6. Dredge output for PTP

\begin{tabular}{|c|c|}
\hline 1. Number of cycle & 4- 5 per day, \\
\hline 2. Hopper capacity $=$ & $2500-5000 / 6000$ \\
\hline 3. Number of days $=$ & $150,000 / 6000$ \\
\hline 4. Volume of maintenance dredging $=$ & $300,000-400,000$ for 3 years \\
\hline 5. Load factor $=$ & $150,000 /$ year \\
\hline 6. Output $=$ & $150,000 / 5000=30,000$ \\
\hline
\end{tabular}

Table 7. Below is guideline for dredger selection given by [UNDP]

\begin{tabular}{|c|c|c|c|c|c|c|}
\hline Site conditions & $\begin{array}{l}\text { Cutter } \\
\text { Suction }\end{array}$ & $\begin{array}{l}\text { Bucket } \\
\text { Wheel }\end{array}$ & $\begin{array}{l}\text { Standard } \\
\text { Trailer }\end{array}$ & $\begin{array}{l}\text { Grab } \\
\text { Hopper }\end{array}$ & $\begin{array}{l}\text { Bucket } \\
\text { chain }\end{array}$ & Grab \\
\hline \multicolumn{7}{|l|}{ Bed arterial } \\
\hline Loose silt & 1 & 1 & 1 & 2 & 2 & 2 \\
\hline Cohessive silt & 1 & 1 & 1 & 1 & 1 & 1 \\
\hline Fine sand & 1 & 1 & 1 & 2 & 2 & 2 \\
\hline Meiumm sand & 1 & 1 & 1 & 2 & 2 & 2 \\
\hline Coarse sand & 1 & 1 & 1 & 2 & 2 & 2 \\
\hline \multicolumn{7}{|l|}{ Sea conditions } \\
\hline Enclosed water & 1 & 1 & 3 & 1 & 2 & 2 \\
\hline Shelter water & 1 & 1 & 1 & 1 & 1 & 1 \\
\hline Exposed water & 3 & 3 & 1 & 3 & 3 & $\mathrm{~N}$ \\
\hline \multicolumn{7}{|l|}{ Disposal to: } \\
\hline Shore & 1 & 1 & 2 & $\mathrm{~N}$ & 2 & 1 \\
\hline Sea & $\mathrm{N}$ & $\mathrm{N}$ & 1 & 1 & 1 & 1 \\
\hline \multicolumn{7}{|l|}{ Quantities } \\
\hline 100,000 cubic meters & 1 & 1 & 2 & 1 & 2 & 1 \\
\hline 250,000 cubic meters & 1 & 1 & 1 & 1 & 1 & 1 \\
\hline 500,000, cubic meter & 1 & 1 & 1 & 2 & 1 & 1 \\
\hline$>500,000$ cubic meter & 1 & 1 & 1 & 3 & 1 & 3 \\
\hline
\end{tabular}

1- Suitability 2-Acceptability 3-Marginal $\mathrm{N}$ - unsuitability 


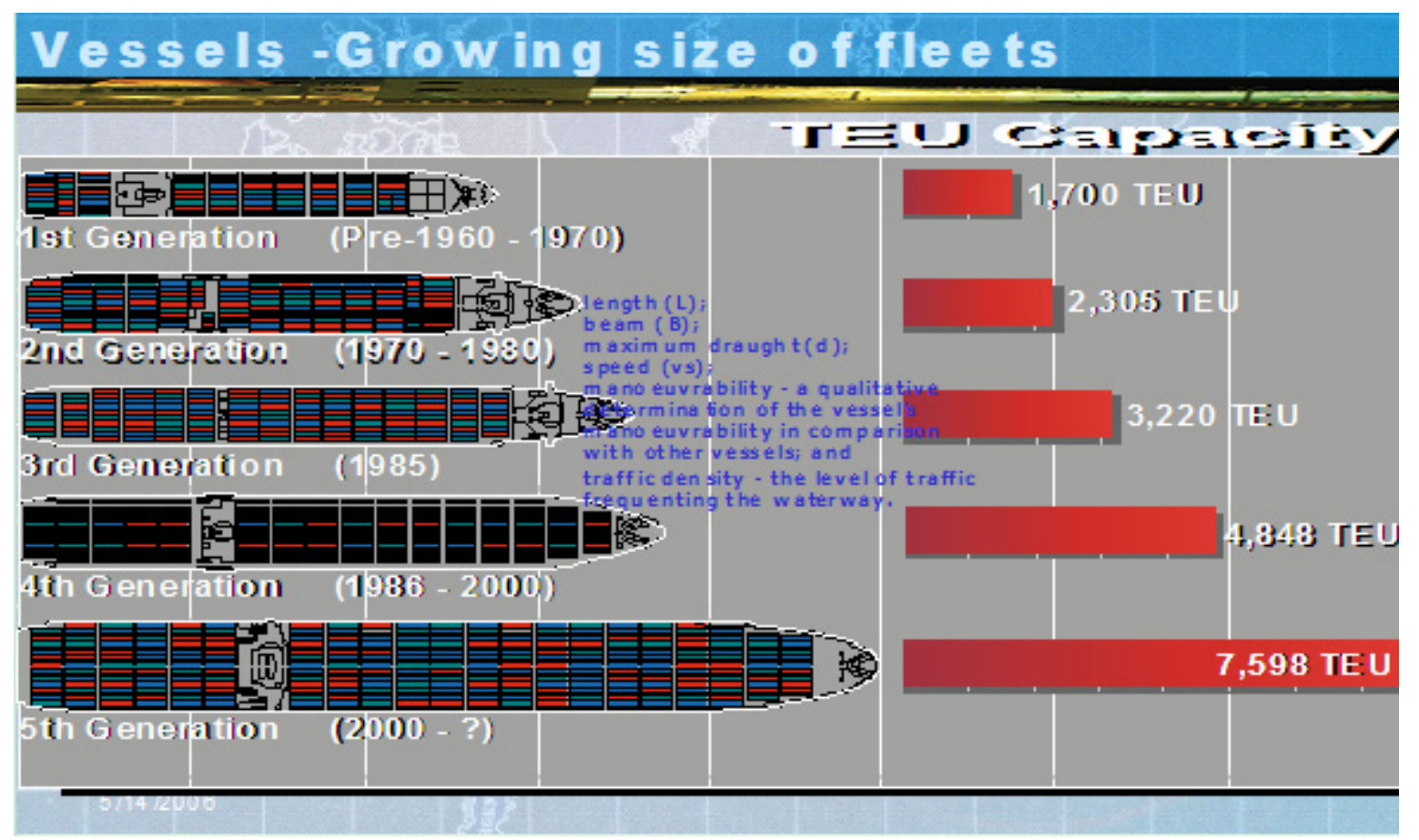

Figure 1. Vessel size increase [Transmarine, 2005]

\section{Channel-condition need}

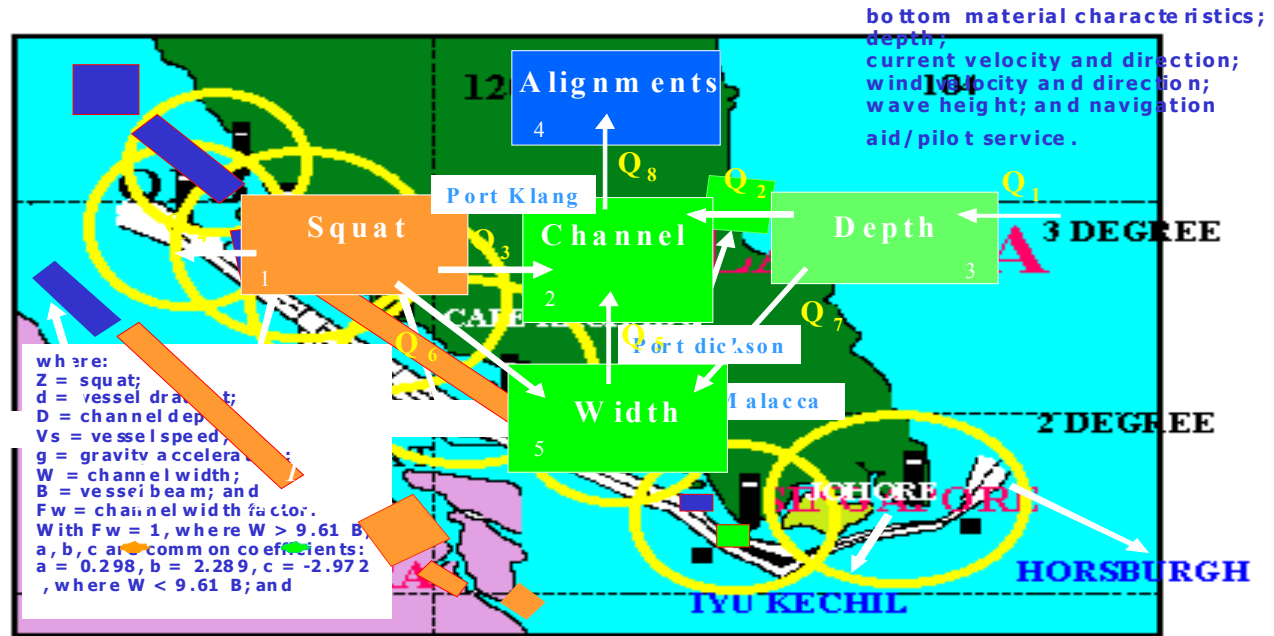

Squat refers to the increase of a ship 's draught

as a result of its motion through water.

Figure 2. The Strait of Malacca and channel requirement 


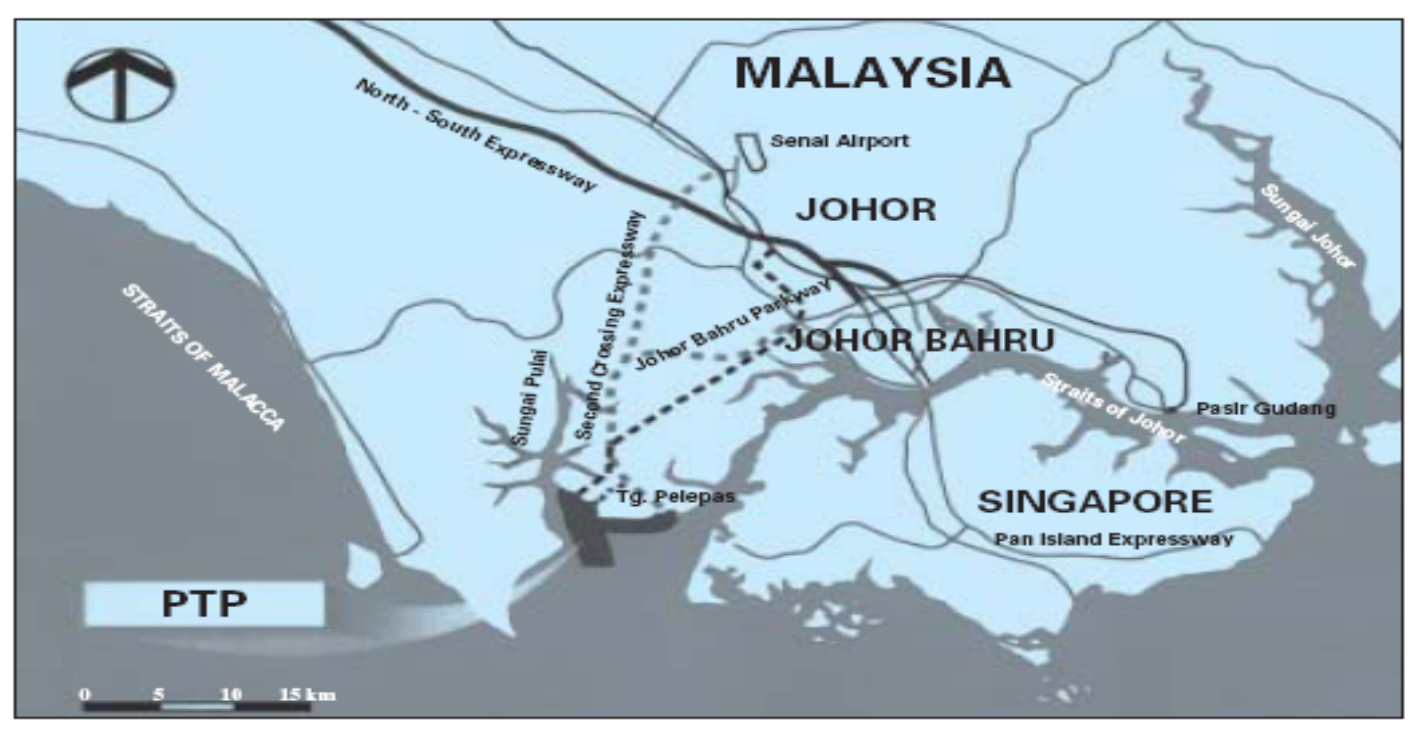

Figure 3. Port Tanjung Pelepas Map

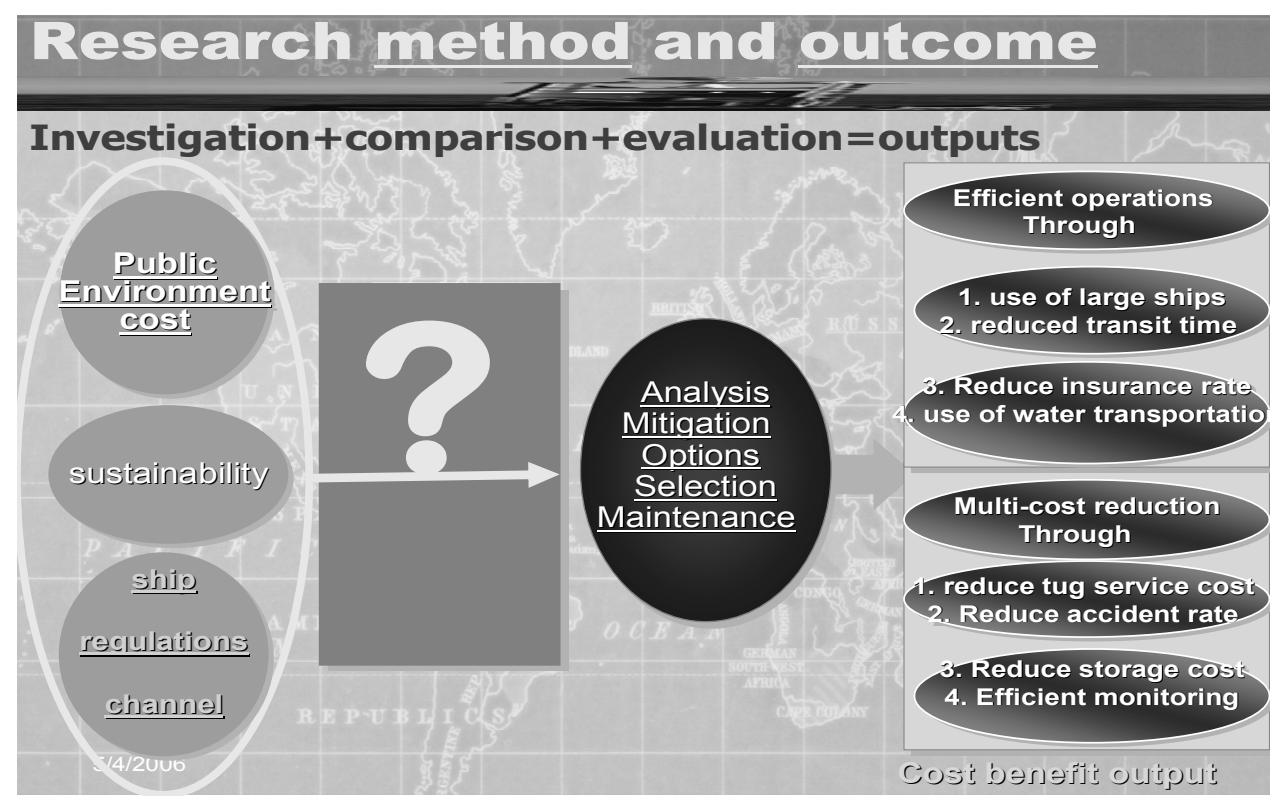

Figure 4. Navigation channel maintenance process 


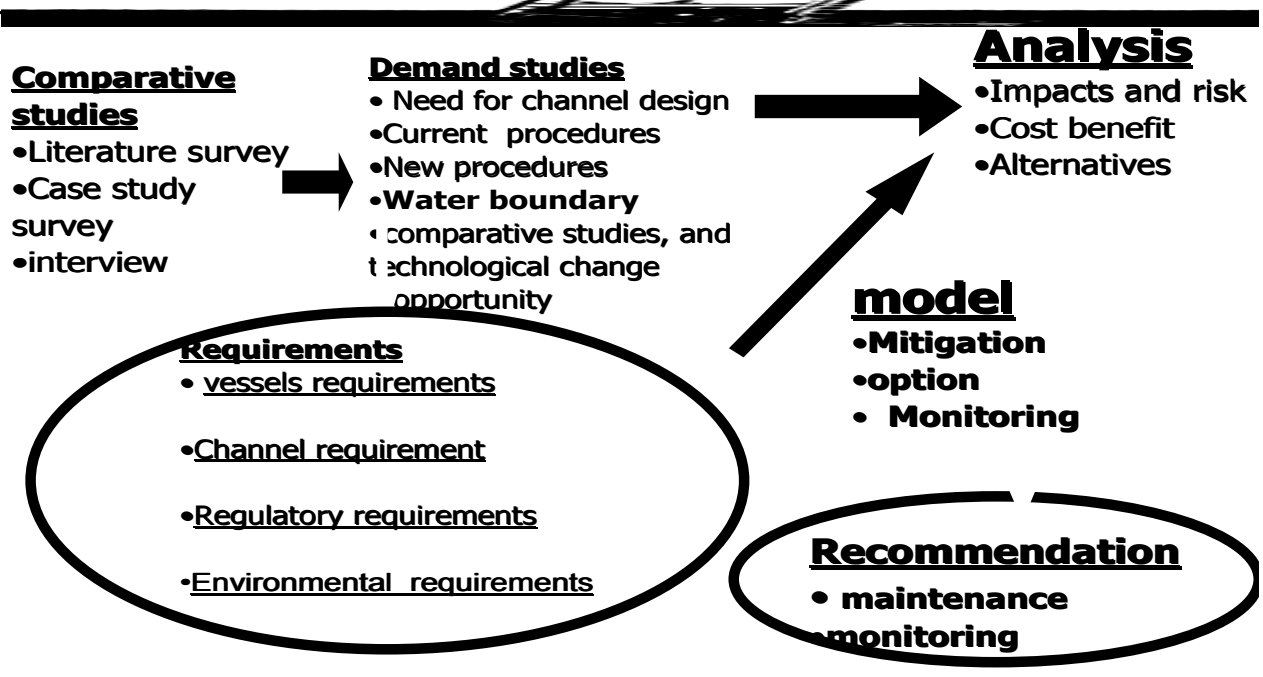

Figure 5. Components of each stage

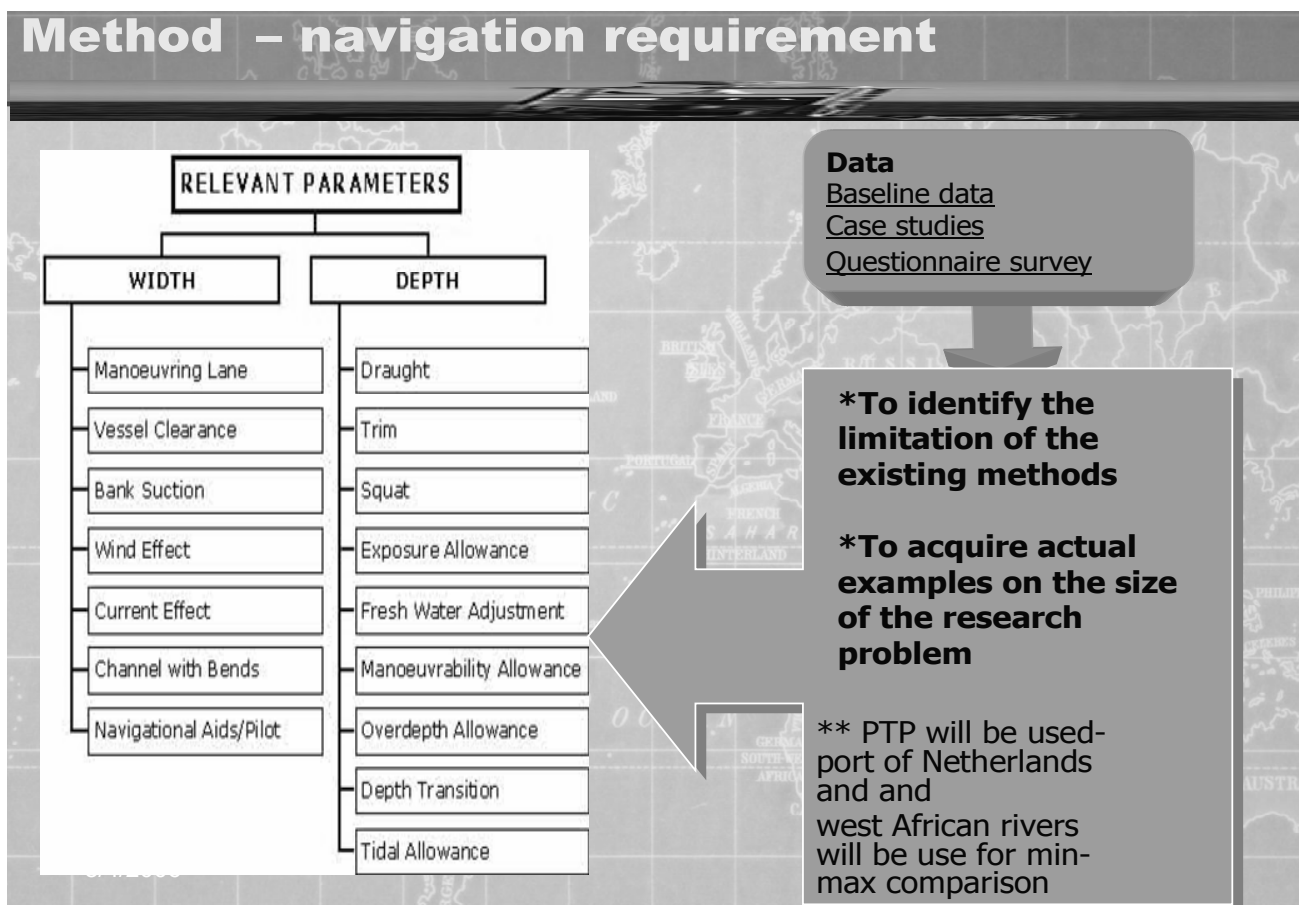

Figure 6. Navigation parameters

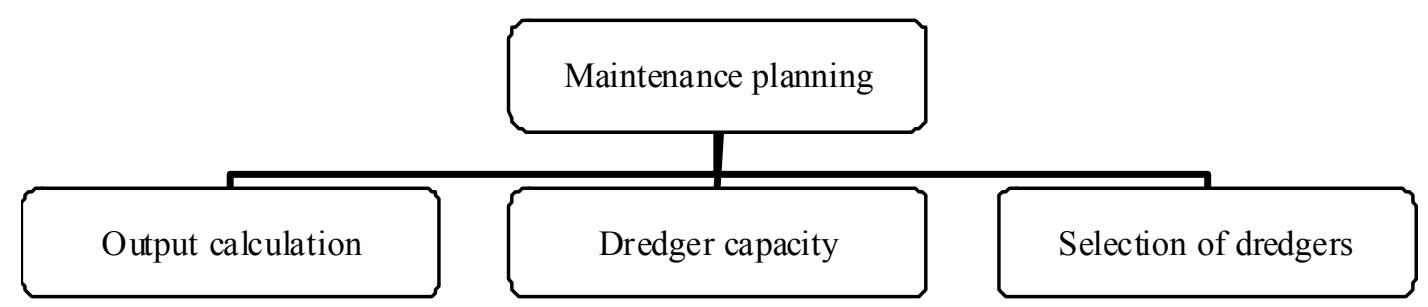

Figure 7. Maintenance dredging components 


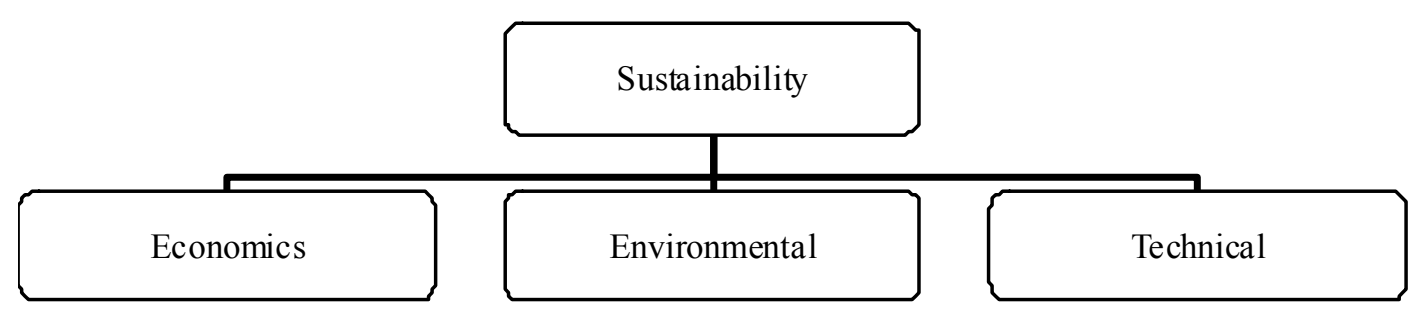

Figure 8. Dredging and sustainability Process

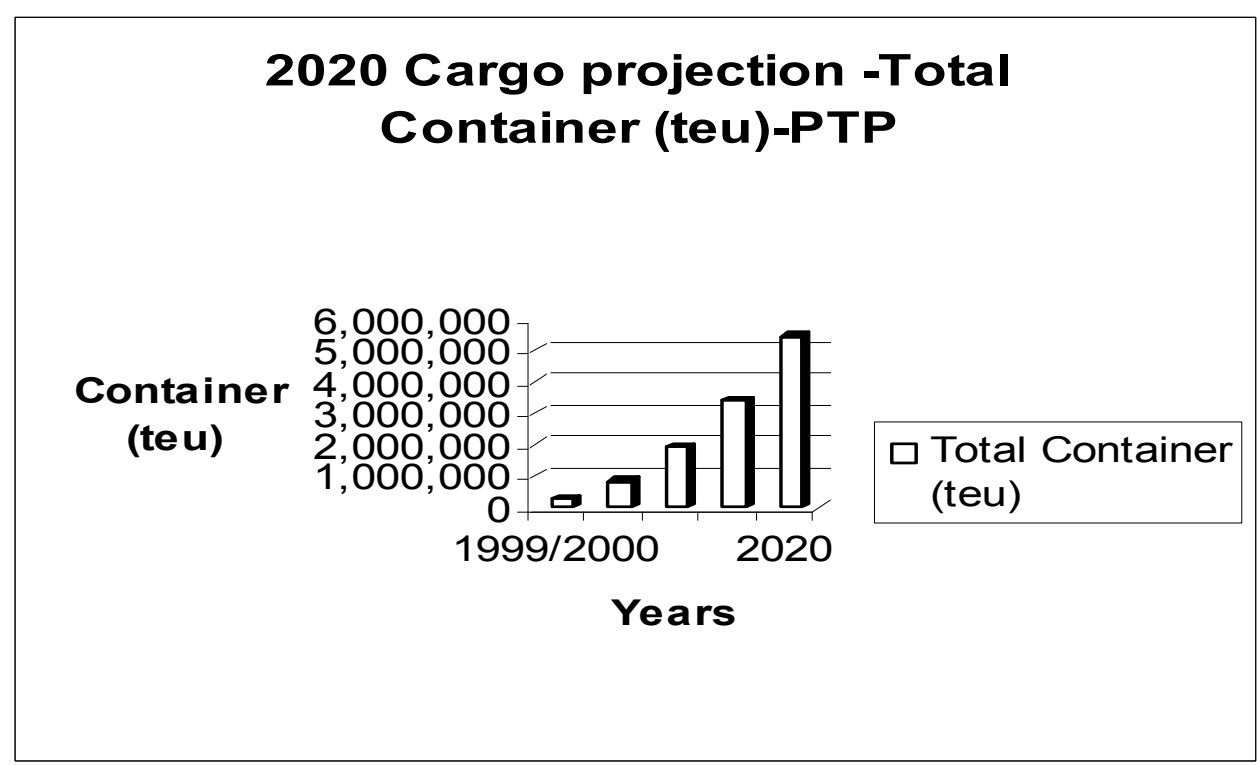

Figure 9. Port output projection

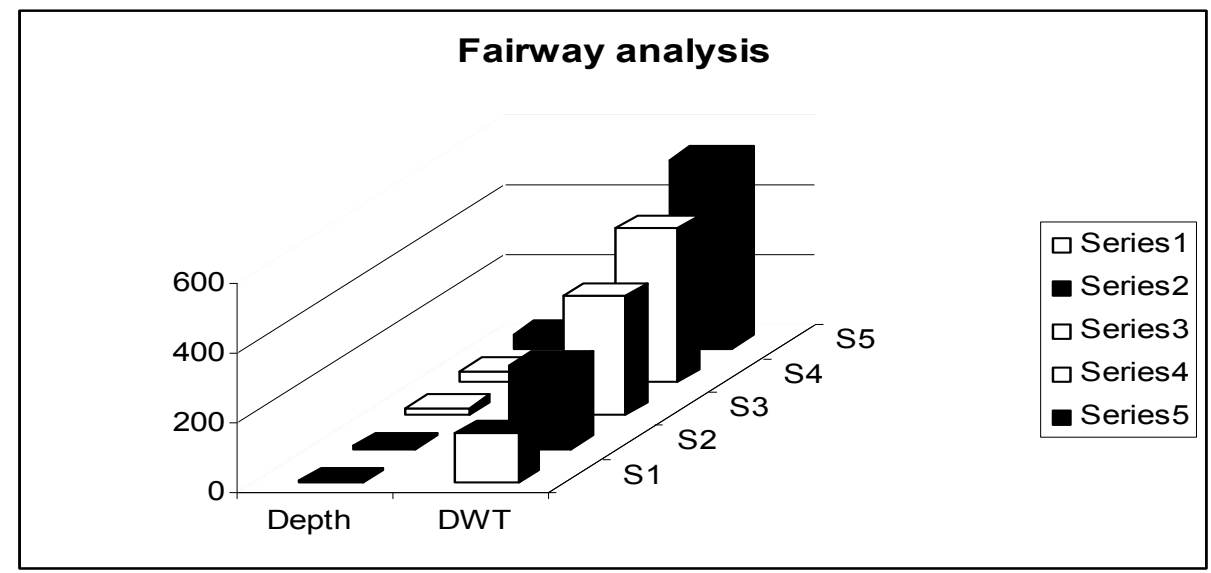

Figure 10. Fairway analysis- Source PTP 


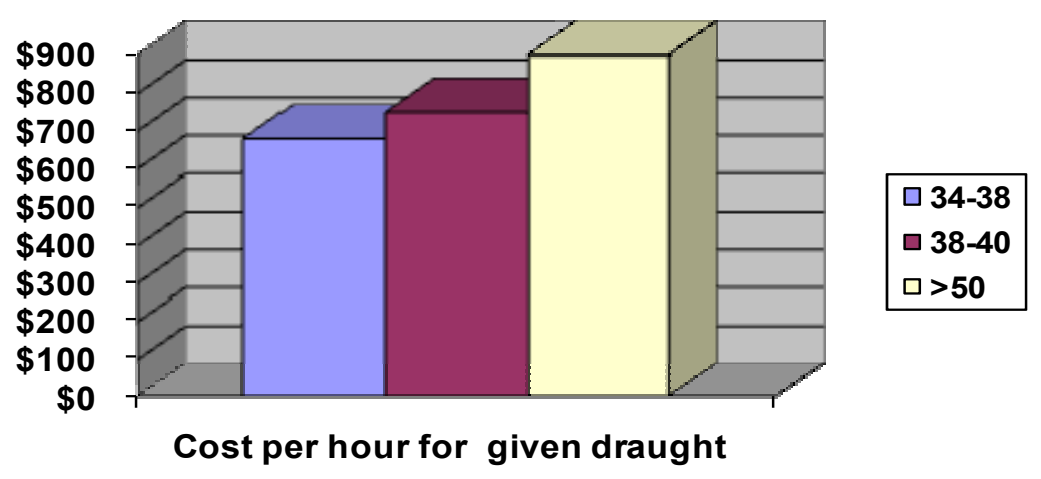

Figure 11. Hourly cost of vessel [UNDP]

Studies made by W. Winkelman estimated time saving in hour as a consequence of deepening of river Scheldt by 4 feet is as follows

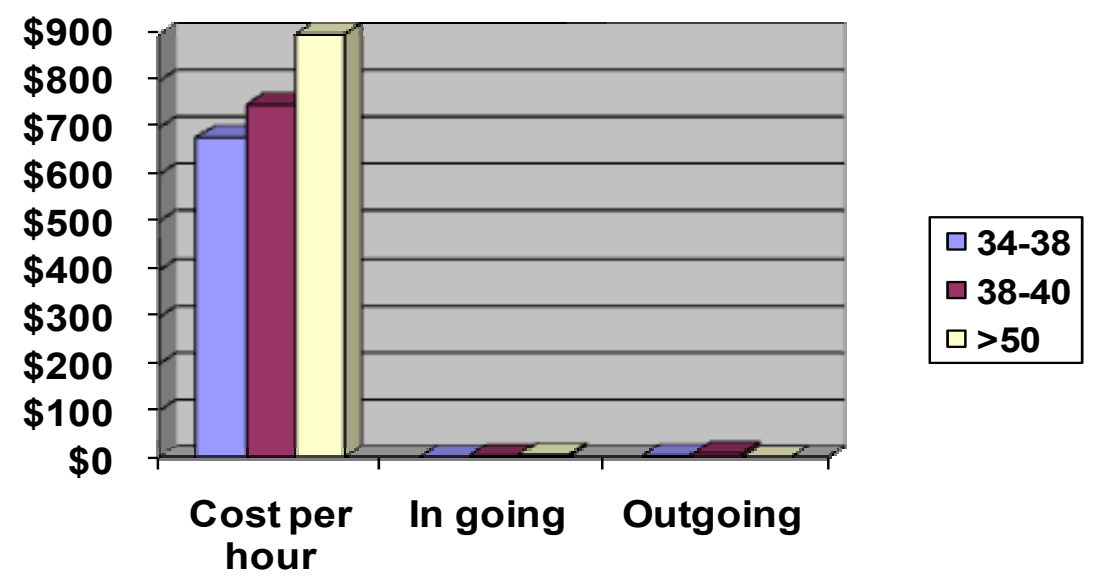

Figure 12. Estimated time due to deepening 


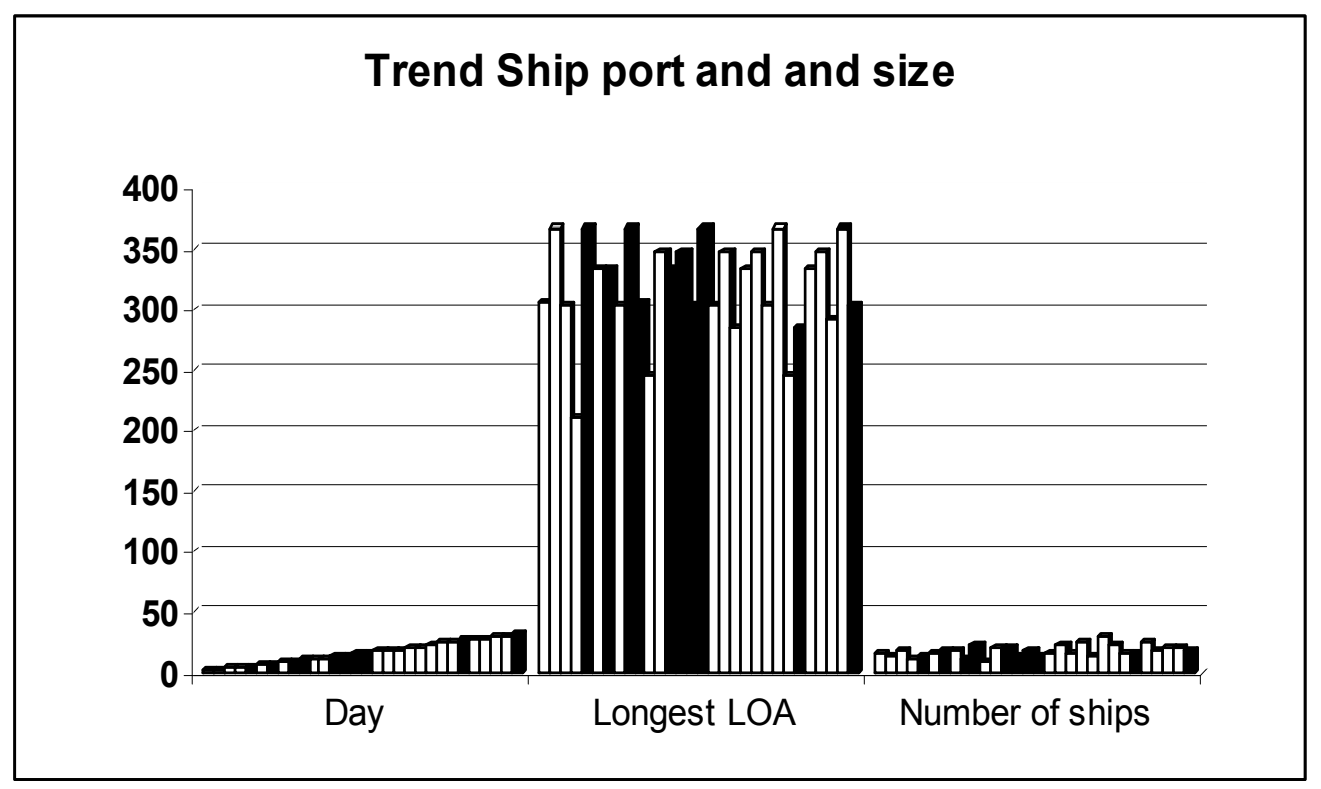

Figure 13. Trends ship calling port, shows trend for day time, longest ship and number of ships calling at PTP [PTP]

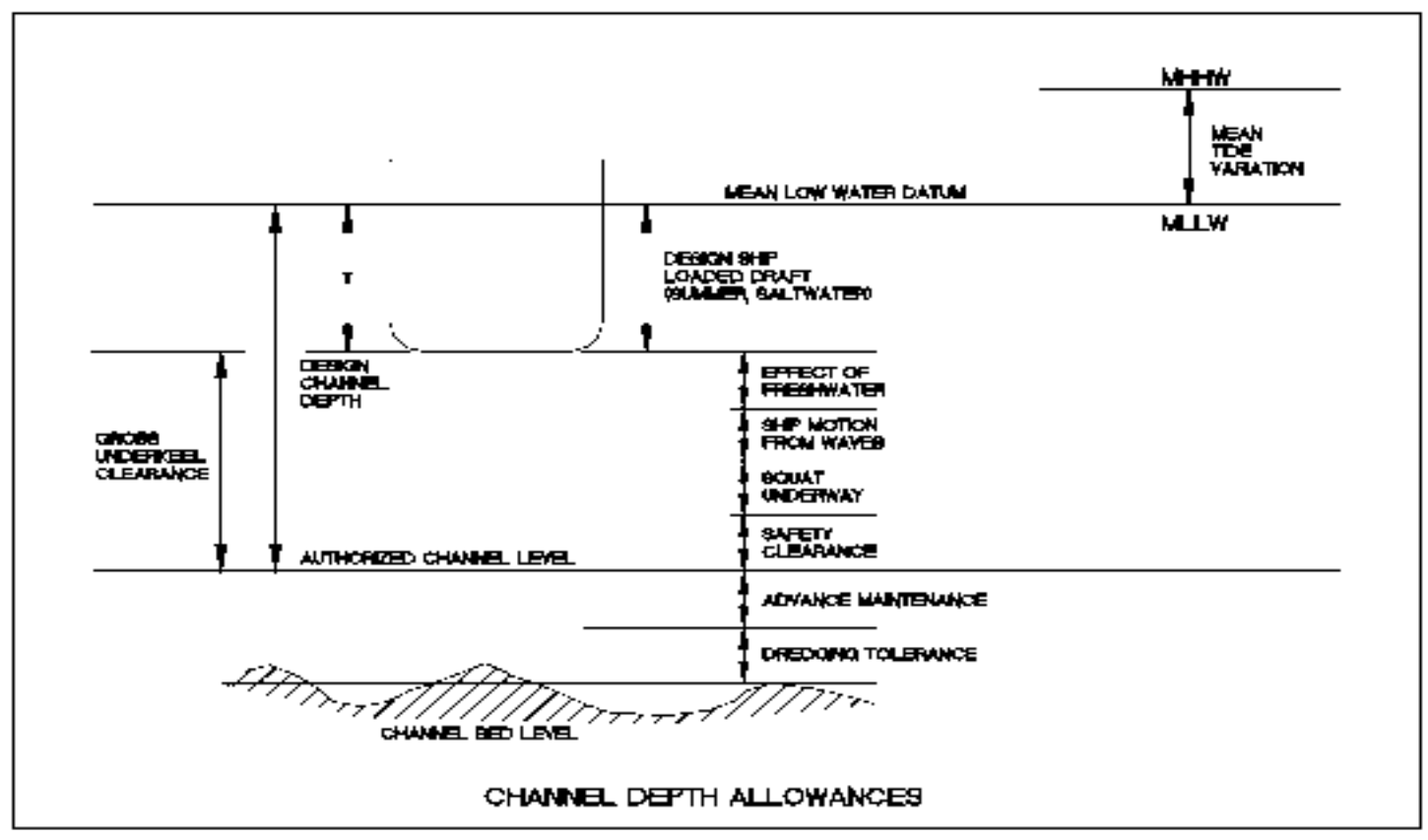

Figure 14. Channel depth allowance 

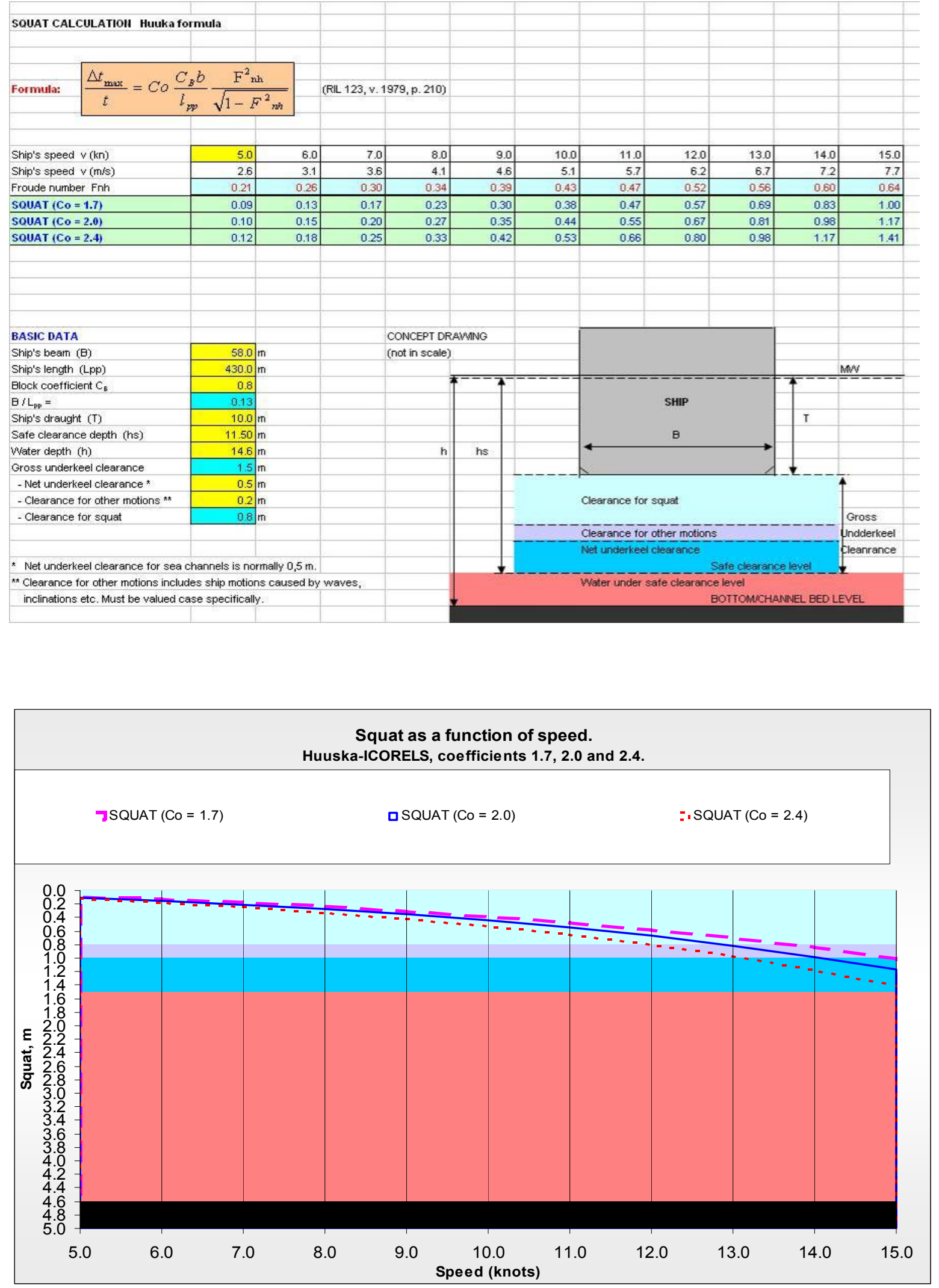

Figure 15. Squat calculation 